РОЗВИТОК СПРИЙНЯТТЯ В ДІТЕЙ З ОБМЕЖЕНИМИ МОЖЛИВОСТЯМИ ЗДОРОВ'Я В УМОВАХ ІНКЛЮЗИВНОї ОСВІТИ

\title{
DEVELOPMENT OF PERCEPTION IN CHILDREN WITH DISABILITIES IN INCLUSIVE EDUCATION
}

\begin{abstract}
у статті розкрито теоретичні аспекти розвитку сприйняття у дітей з обмеженими можливостями здоров'я в умовах інклюзивної освіти мультисенсорним методом. Інтеграційні процеси в сучасних загальноосвітніх організаціях диктують необхідність створення інклюзивного простору, коли діmи з обмеженими можливостями здоров'я зі збереженим інтелектуальним розвитком навчаються за адаптованими основними освітніми програмами в одному класі (групі) зі здоровими однолітками. Це змушує шукати інноваційні шляхи навчання, що сприяють удосконаленню й корекції сприйняття у дітей з важкими порушеннями мови (ВПМ) та / або із затримкою психічного розвитку (ЗПР).

У всіх проаналізованих наукових працях пропонується так чи інакше використовувати мультисенсорний метод подачі освітньої інфрормації в груповій роботі з молодшими школярами, які мають ВПМ та ЗПР, відповідно, саме його можна виділити в якості універсального, що застосовується в умовах інклюзії стосовно всіх категорій учнів.

Методика застосування мультисенсорного методу передбачає використання прийомів, які об'єднують слухове сприйняття пояснень педагога із зоровим сприйняттям демонстраційного матеріалу та підкріпленням предметно-практичними діями. Цей метод подачі навчальної інформації полягає в тому, що кожне нове словесне звернення педагога базується на залученні слухової модальності, підкріплюється зоровими й тактильно-кинестичними стимулами.

Різними емпіричними дослідженнями доведено дисгармонічність взаємопов'язаного сприйняття як при ВПМ, так і при ЗПР, проте наявні рекомендації щодо його фрормування в освітньому процесі містять методику тільки в умовах дифререниійованого навчання, а че суперечить сучасним освітнім тенденціям інклюзивного навчання.
\end{abstract}

к.пед.н.

доцент кафедри сімейної та спеціальної педагогіки і психології

Південноукраїнський національний

педагогічний університет

імені К.Д. Ушинського
Ключові слова: сприйняття, інклюзивна освіта, мультисенсорний метод.

The article reveals the theoretical aspects of the development of perception in children with disabilities in an inclusive education by multi-sensory method. Integration processes in modern secondary schools dictate the need to create an inclusive space, when children with disabilities with preserved intellectual development study, albeit in adapted basic educational programs, but in the same class (group) with healthy peers. This forces us to look for innovative ways of learning that contribute to the improvement and correction of perception in children with severe speech disorders and / or mental retardation. In all analyzed scientific works it is suggested to use one way or another the multisensory method of presenting educational information in group work with younger students with severe speech disorders and mental retardation, respectively, it can be distinguished as universal, applied in terms of inclusion to all categories of students.

The method of application of the multisensory method involves the use of techniques that combine the auditory perception of the teacher's explanations with the visual perception of the demonstration material and the reinforcement of subject-practical actions. This method of presenting educational information is that each new verbal appeal of the teacher is based on the involvement of auditory modality, supported by visual and tactile-kinetic stimuli.

Various empirical studies have proven the disharmony of interrelated perception in both severe speech disorders and mental retardation, however, the available recommendations for its formation in the educational process contain methods only in terms of differentiated learning, it contradicts modern educational trends of inclusive education.

Key words: perception, inclusive education, multisensory method.
Постановка проблеми. Поняття інклюзії, на відміну від поняття спеціальної освіти, 3'явилося в Україні ще на початку XXI століття. Пошук шляхів підвищення ефективності корекційної роботи в умовах інклюзивної освіти через розвиток сприйняття $€$ актуальним у спеціальній психології та педагогіці, де інклюзія розглядається з позицій забезпечення рівного доступу до освіти для всіх учнів з урахуванням різноманітності особливих освітніх потреб та індивідуальних можливостей. Найчастіше інклюзивною освітою бувають охоплені діти з важкими порушеннями мови та затримкою психічного розвитку. Недоліки сприйняття цих категорій дітей відзначаються різними дослідниками, рекомендації яких стосуються в основному диференційованої спеціальної освіти. До позитивних аспектів інклюзивної освіти відносять те, що дитина з різними обмеженнями можливостей здоров'я (ОМЗ) не перебуває в середовищі подібних до себе дітей, а інтегрується в реальне суспільство, може здобувати освіту в одній групі (класі) разом зі здоровими дітьми. При цьому у здорових однолітків, що проходять через інклюзивну освіту, виховується співпереживання та розуміння, товариськість і терпимість. Все це вимагає перегляду традиційних методів освіти та пошуку результативних шляхів навчання дітей з ОМЗ для максимального освоєння ними адаптованих основних освітніх програм в умовах інклюзії. 
Інтеграційні процеси в сучасних загальноосвітніх закладахдиктують необхідністьстворення інклюзивного простору, коли діти з ОМЗ із збереженим інтелектуальним розвитком (при важких порушеннях мови (ВПМ) та / або затримкою психічного розвитку (ЗПР)) навчаються хоч і за адаптованими основними освітніми програмами, але в одному класі (групі) зі здоровими однолітками. У такому разі будь-який педагог змушений вести мовлення навчальної інформації одночасно для дітей з ОМЗ й для «здорових» однолітків. Це змушує шукати інноваційні шляхи навчання, що сприяють удосконаленню й корекції сприйняття у дітей з ВПМ та / або ЗПР, одночасно полегшують і здоровим дітям опановування змістом освітніх програм. Такі підходи можна використовувати будь-якому педагогу в процесі інклюзивної освіти.

Аналіз останніх досліджень і публікацій. Аналізуючи літературні джерела (Е. Дж. Айрес, М.С. Бурлакова, Т.Г. Візель, В.А. Ковшікова, А.Р. Лурія, В.В. Опель, Л.С. Цвєткова та інші), ми виявили, що в науці існує дефіцит емпіричних досліджень, які вивчають розвиток сприйняття дітей з ВПМ або із ЗПР саме в умовах інклюзивної освіти. Однак всі вищезгадані дослідники привнесли важливий внесок у вивчення проблеми розвитку сприйняття у даних категорій дітей, їх аналіз дозволяє виділити універсальні підходи подачі інформації, які можливо адекватно використовувати педагогу на занятті з дітьми 5-7 років в інклюзивному освітньому середовищі.

Постановка завдання. Вивчення науково-методичної літератури показало недостатню освітленість цього питання. У зв'язку з цим виникає необхідність проаналізувати та узагальнити результати різних досліджень сенсорно-перцептивної сфери людини, визначити універсальний метод подачі освітньої інформації, що сприяє вдосконаленню сприйняття при інклюзивному навчанні.

Основу дослідження склали праці різних вчених XX-XXI століть. Основним методом, що використовувався, був теоретичний метод, який передбачає вивчення та аналіз психолого-педагогічної літератури з проблеми розвитку сприйняття в учнів, включаючи: порівняно-історичний аналіз розвитку та корекції вад до когнітивного й мовного розвитку з використанням принципу опори на аферентації, а також аналіз стану сенсорно-перцептивної сфери в учнів; узагальнення, аналіз пропонованих методів подачі освітньої інформації, їх порівняння та аналітичні висновки.

Методики корекції сенсорно-перцептивної сфери дітей з ОМЗ виникли на базі розробок ефективних шляхів подолання когнітивних недоліків при ВПМ у осіб різних вікових груп, починаючи з дорослих та закінчуючи дошкільнятами.
У фундаментальних працях відомого нейропсихолога А.Р. Лурії було закладено положення про взаємозалежну (спільну) роботу зорового, слухового та тактильно-кінестетичного сприйняття при прийомі та переробці інформації у здорової людини та її порушення у хворих з різними травмами головного мозку [8]. Ще в середині $X X$ століття як відновлювальну терапію при когнітивних порушеннях, зумовлених травматичною афазією, А.Р. Лурія пропонував принцип опори на взаємопов'язані аферентації [8]. Пізніше Л.С. Цвєткова та її послідовники розширили застосування цього принципу, пропонуючи його використання при всіх формах афазії, вказуючи на полірецепторність їх «аферентного поля» та «запасний фонд» аферентацій [14; 15].

Багато авторів другої половини XX століття так чи інакше посилалися на необхідність застосування принципу опори на взаємопов'язаність аферентації в процесі навчання при афазії та корекції алалії у дорослих, підлітків та дітей. До них належать роботи Т.Г. Візель, В.В. Опель про відновлення промови після інсульту; М.С. Бурлакова про коррекційно-педагогічну роботу при афазії; В.А. Ковшікова про методи усунення алалії, тощо $[4 ; 6 ; 10 ; 16]$.

Безпосередньо дослідження взаємопов'язаного сприйняття продовжилися на початку XXI століття. Серед них слід відзначити роботу Т.Н. Бандурка [3], в якій характеризується структура взаємопов'язаного сприйняття студентів лінгвістичних закладів вищої освіти, які вивчають іноземну мову, і доводиться можливість його вдосконалення в учнів в освітньому процесі.

У своїй експериментальній роботіГ.А. Ванюхина, звернувшись до ідеї «взаємопов'язаності сприйняття», пропонувала удосконалювати монологічні здатності старших дошкільників із загальним недорозвиненням мови шляхом опори на сенсорну домінанту. Автор радить програмну інформацію подавати на основі діагностики з урахуванням провідного сенсора, але одночасно необхідно представляти іï також полісенсорно.

Виклад основного матеріалу. Порівнявши всі вищеописані дослідження вибірок учнів з ВПМ та ЗПР в віковому діапазоні 5-7 років, ми виявили таку закономірність. Попри те, що у дітей були умовно здорові зоровий, слуховий та тактильно-кінестетичний аналізатори, тобто медичні та інші обстеження окремо не виявляли істотних патологій у їх функціонуванні, у них страждала саме взаємопов'язаність сприйняття й міжаналізаторна переробка одержуваної інформації. Це створює складності в здійсненні повноцінного освітнього процесу та вимагає використання спеціальних методів подачі навчальної інформації, удосконалюючи взаємопов'язаність сприйняття. 
У всіх проаналізованих наукових працях пропонується так чи інакше використовувати мультисенсорний метод подачі освітньої інформації в груповій роботі з молодшими школярами, які мають ВПМ та ЗПР, відповідно, саме його можна виділити як універсальний, що застосовується в умовах інклюзії до всіх категорій учнів.

Метод мультисенсорної подачі інформації передбачає, що все мовлення здійснюється одночасно на три модальності сприйняття (слухову, зорову та тактильно-кінестетичну). Провідним способом подачі інформації та особливостями ії переробки тут, незалежно від індивідуальних типів профілів взаємопов'язаного сприйняття дітей, $є$ засвоєння інформації різних модальностей шляхом практичних дій 3 нею на основі включення в пізнавальний процес різних аналізаторів. Внаслідок цього відбувається підвищення ефективності сенсорної уваги й пам'яті засобами взаємопов'язаного аналізу інформації в процесі її активної обробки з обов'язковим здійсненням практичних дій.

Методика застосування мультисенсорного методу передбачає використання прийомів, які об'єднують слухове сприйняття пояснень педагога із зоровим сприйняттям демонстраційного матеріалу та підкріпленням предметно-практичними діями (тактильно-кінестетичний аспект аналізу інформації).

Важливо, наприклад, всі словесні пояснення педагога, що транслюються на слухову модальність, обов'язково супроводжувати й наочним матеріалом (запускаючи зоровий канал), й активною жестикуляцією (включаючи кінестетичне сприйняття). Також за можливості слід залучати тактильний канал, даючи дітям самостійно сприйняти форму, вагу, положення, температуру, жорсткість, м'якість об'єкта та інші його якості.

Разом з тим при вербальних зверненнях педагога до дітей необхідно одночасно використовувати лексику всіх трьох модальностей сприйняття, наприклад, «Послухайте (почуйте, озвучте, опишіть); подивіться (погляньте), відчуйте (спробуйте, побудуйте)» тощо. Корисне застосування методичних прийомів, коли діти виконують комбіновані дидактичні завдання та ігри. Наприклад: «Намалюй вірші руками».

Аналогічно відбувається й комбінування різних способів оцінки дитячої діяльності, коли поєднується використання вербальної оцінки з картинками, наприклад, зображення смайлика (посміхається, хмуриться) з заохоченням дитини за правильну відповідь тактильним підтвердженням (погладжування по голові, по плечу).

Вищеописані прийоми можливо одночасно застосовувати як до здорових дітей, які навчаються в класі (групі), так і до учнів з ОМЗ. Проте в груповому інклюзивному навчанні до дітей з обмеженими можливостями здоров'я слід здійснювати індивідуально-диференційований підхід, з урахуванням не тільки негативних характеристик їx взаємопов'язаного сприйняття, але й структури дефекту. У зв'язку з цим розглянемо можливості застосування мультисенсорного методу, здійснюючи індивідуально-диференційований підхід у ставленні до дітей певного типу ОМЗ.

При ВПМ, по-перше, спостерігається недорозвинення різних сторін мови, в тому числі й фонематичного сприйняття, а по-друге, виявляються недоліки узагальнюючої (пізнавальної) та комунікативної функції мови, що зумовлює труднощі відтворення дітьми навчального матеріалу на вербальному рівні. Це викликає необхідність переважного спілкування з цими учнями в діалоговій формі, одночасного здійснення застосування мультисенсорного методу подачі та аналізу інформації.

Первинна затримка темпу психічного розвитку може супроводжуватися незрілістю емоційно-вольової сфери, астенічними, невротичними розладами, викликати часті перевтоми, що порушують працездатність на уроці (занятті).

В інклюзивному навчанні дітям із ЗПР педагог повинен додатково пропонувати мультисенсорні стимули зняття перенапруги. Наприклад, зорові стимули: закрити очі; подивитися на колір, на який хочеться довго дивитися; подивитися на улюблений смайлик; моргнути; тактильно-кінестетичні стимули: потрясти руками; затиснути пальці; потягнутися; слухові стимули: щільно затискати руками вуха та відпускати; закривати вуха спеціальною пов'язкою. Поступово ці діти зможуть навчитися самостійно дозувати навантаження, автономно вибирати кращий для себе стимул при перших ознаках стомлення, не відволікаючи педагога та інших учнів.

Таким чином, можна стверджувати, що мультисенсорний метод подачі інформації доступний для використання всім педагогам, він максимально сприяє розвитку взаємопов'язаного сприйняття учнів з ОМЗ, що своєю чергу, підвищує ефективність засвоєння цими дітьми програмного матеріалу.

Різними емпіричними дослідженнями доведено дисгармонічність взаємопов'язаного сприйняття як при ВПМ, так і при ЗПР, проте наявні рекомендації щодо його формування в освітньому процесі містять методику тільки в умовах диференційованого навчання, а це суперечить сучасним освітнім тенденціям інклюзивного навчання. Пошук шляхів підвищення ефективності корекційної роботи спонукав до аналізу й узагальнення наукових уявлень про проблему розвитку взаємопов'язаного сприйняття. У визначенні адекватних підходів до її вирішення ми зупинилися на виділенні універсального методу подачі 
навчальної інформації, застосування якого в умовах інклюзії дозволить підвищити ефективність засвоєння всіма учнями програмного змісту будь-яких занять (уроків), отже його можливо використовувати будь-якому педагогу при спільному навчанні як здорових дітей, так і дітей, що мають ВПМ та/або ЗПР.

Висновки 3 проведеного дослідження. Проведене теоретичне дослідження дозволило нам зробити ряд висновків. Практично всіма вченими, що досліджували сенсорно-перцептивну сферу людини, визнається важлива роль взаємопов'язаного сприйняття в пізнавальному й мовному розвитку.

У всіх дослідженнях, проведених з дітьми старшого дошкільного віку, автори прямо вказують на негативні характеристики взаємопов'язаного сприйняття учнів з ВПМ та/ або з ЗПР, попри умовно здорові у них зоровий, слуховий, чуттєвий та руховий аналізатори, і рекомендують застосовувати інноваційні методи подачі освітньої інформації в педагогічній роботі з ними, що полегшують сприйняття навчальної інформації та сприяють удосконаленню структури взаємопов'язаного сприйняття дітей з ВПМ та ЗПР.

Як універсальний метод, який найбільш повно реалізує принцип максимальної опори на взаємопов'язаність аферентації, який можна використовувати в інклюзивному освітньому процесі, виділяється мультисенсорний. Цей метод подачі навчальної інформації полягає в тому, що кожне нове словесне звернення педагога базується на залученні слухової модальності та підкріплюється зоровим й тактильно-кінестичним стимулами. При цьому в груповому інклюзивному навчанні до дітей з ОМЗ слід здійснювати індивідуально-диференційований підхід, з урахуванням не тільки негативних характеристик їх взаємопов'язаного сприйняття, але й структури дефекту.

\section{ЛІТЕРАТУРА:}

1. Айрес Э.Дж. Ребенок и сенсорная интеграция. Понимание скрытых проблем развития; пер с англ. Ю. Даре. Москва : Теревинфр, 2017. 272 с.
2. Актуальные проблемы нейропсихологии детского возраста: Учебное пособие. Изд-во Московского психолого-социального института; Воронеж: МОДЭК, 2006. 296 c.

3. Бандурка Т.Н. Взаимосвязь восприятия в обучении. Как раздвинуть границы познания : монографрия. Иркутск : «Отпечаток», 2005. 204 с.

4. Бурлакова Н.С. Коррекционно-педагогическая работа при афазии: Кн. для логопедов. Москва : Просвещение, 1991. 192 с.

5. Ванюхина Г.А. Использование полисенсорного восприятия В процессе коррекции связных высказываний у дошкольников с общим недоразвитием речи : дис. ... канд. пед. Наук : 13.00.03. Екатеринбург, 2003. 203 с.

6. Ковшиков В.А. Экспрессивная алалия и методы ее преодоления: учебное пособие ; 4е изд., Испр. и доп. Санкт-Петербург : КАРО, 2018. 304 с.

7. Логопедия. Методическая наследие. Москва : ВЛАДОС, 2007. 311 с.

8. Лурия А.Р. Основы нейропсихологии: учеб. пособие. Москва : Академия, 2003. 384 с.

9. Мурашова И.Ю. Психокоррекция нарушений речевого развития с использованием инновационных подходов : учебное пособие. Москва : Знание, 2020. $104 \mathrm{C}$

10. Опель В.В. Восстановление речи после инсульта. Ленинград : Медицина, Ленинград. 1972. $152 \mathrm{c}$.

11. Орфинська В.К. Сравнительный анализ нарушений речи при афразии и алалии : автореф. дис. ... канд. психол. наук. Ленинград, 1960. 26 с.

12. Практикум по дошкольной логопедии. Москва : Просвещение, 1988. 222 с.

13. Соботович Е.Ф. Формування правильного мовлення в дітей 3 моторною алалією : навч. посіб. Київ : КГПИ, 1981. 150 с.

14. Цветкова Л.С. Афразия и восстановительное обучение : учеб. пособие. для студентов десектол. фак. пед. др.-то. Москва : Просвещение. 1988. 207 с.

15. Цветкова Л.С. Занятия и восстановления речи при афразии. Принципы и методы обучения при афразии. Москва : ВЛАДОС, 2007.Системние нарушение речи. Алалия. Асразия. С. 265-270.

16. Шкловский В.М., Визель Т.Г. Восстановление речевой функции у больных с различными фрормами афразии. Москва : Ассоциация дефектологов, 2000. 96 c. 